\title{
Physico-chemical properties of mango pulp and cajarana blends
}

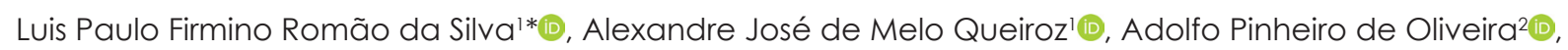

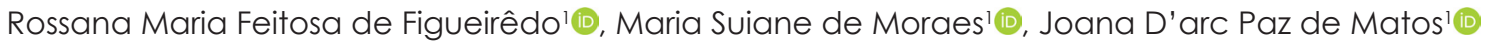

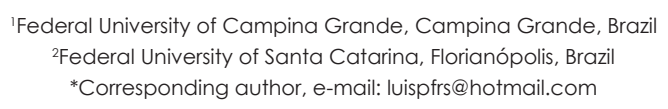

\begin{abstract}
The mango and cajarana are pleasant-tasting fruits, yellow in color, have ascorbic acid with antioxidant properties that slow down oxidation and help the immune system to promote well-being. The production of blends can improve nutritional and sensory characteristics, combining macro and micronutrients that may be present in a higher concentration in one fruit and deficient in another, increasing the possibility of obtaining new flavors constituting a new product. The study had as objective the elaboration of blends of mango cv. espada and cajarana and to determine the physical-chemical characteristics and color parameters. Three formulations were prepared: $\mathrm{Fl}-50 \%$ mango pulp and $50 \%$ cajarana pulp; $\mathrm{F} 2-90 \%$ mango pulp and $10 \%$ cajarana pulp and F3 - 10\% mango pulp and $90 \%$ cajarana pulp. The formulations were evaluated for physicochemical parameters of water activity, moisture content, ash, total soluble solids, pH, total titratable acidity, ascorbic acid, proteins, lipids, total sugars, reducers, non-reducers and color parameters. The data obtained were submitted to analysis of variance and comparison between means by the Tukey test. The blends caused significant changes in most of the parameters evaluated, with an increase in the moisture content, ash, total titratable acidity, proteins and lipids as the concentration of the cajarana pulp was increased. The increase in the proportion of mango pulp favored the achievement of lighter blends, with a predominance of yellowness. However, the development of blends from this study presents itself as a viable alternative for the use of fruit pulps, both in terms of nutrition, complementing the nutrient content through this mixture as a very promising product for the market.
\end{abstract}

Keywords: Mangifera indica L., Spondias dulcis Parkinson, fruit pulps, development, quality

\section{Introduction}

During the last decades, the population is increasingly looking to insert plant products with a high content of vitamins, anthocyanins and phenolic compounds into their usual diet, this interest comes from several studies that report that the consumption of these components can bring health benefits (Corbo et al., 2014; Henrique et al., 2016; Buniowska et al., 2017).

Mango (Mangifera indica L.) belongs to a group of tropical fruits that has become increasingly important in the market and has significant commercial value. Features such as juiciness, exotic flavor and nutritional value stand out so that this fruit is widely consumed. In addition, mango is a rich source of health-promoting compounds, such as carotenoids, ascorbic acid, quercetin and mangiferin (Lauricella et al., 2017).

The total world production of mango was around 50 million tons in the year 2017, this crop is among the most important in the global scenario. Countries such as India, China, Kenya, Thailand, Indonesia, Mexico and Pakistan account for more than $75 \%$ of mango production worldwide (Fao, 2020). In addition to consumption as ripe fruit, these are generally processed into juices, jams and drinks (Ravani \& Joshi, 2013; Asif, 2016).

The fruits of the cajaraneira (Spondias dulcis Parkinson or Spondias cythera Parkinson) have different names, such as cajarana, cajá-mango, cajá-anão, among others depending on the region where it is grown. Due to its nutritional composition, the presence of bioactive compounds such as antioxidants, carotenoids and vitamins, cajarana has gained space among scientific studies seeking to explore its properties and product development (Lima et al., 2012).

The cajarana has aroused interest in the food industry due to its potential to be used in the production of juices, jellies, nectar, ice cream and some beverages 
such as wines and liqueurs, with low manufacturing costs (Cheuczuk et al., 2018).

In Brazil, the standards of identity and quality of fruit juice and pulp are regulated by Normative Instruction $n^{\circ} 49$ (Brasil, 2018a) and Normative Instruction n 37 (Brasil, 2018b). In the normative instruction, the standards for mango are contemplated without specifying the variety and for cajá (Spondias lutea L.) which is of the same genus as cajarana, and there is no standard for cajarana. The quality of fruit pulp is related to the preservation of sensory, physical-chemical and nutrient characteristics, which must be close to that of fresh fruit, thus meeting the demands of consumers and the legislation itself. Thus, values of parameters such as $\mathrm{pH}$, total soluble solids, total solids, total acidity, total sugars, ascorbic acid, among others, are mentioned in the legislation for each type of fruit, according to their characteristics.

The mixtures of pulps, juices and nectars are called blends, designed to improve the nutritional and sensory characteristics of the components consumed in isolation, it is configured as an alternative to processing surplus fruit during the harvest and adding value to the product (Gadelha et al., 2019). Through this combination, numerous products can be developed with characteristics that can be chosen according to the profile of the consumer to be reached (Lemos et al., 2013).

The consumption of fruit pulp is constantly growing, so it is believed that a blend with regional fruits (mango cv. espada and cajarana) may be an alternative for the technological use of these raw materials, seeking their commercial valorization and offering to the competitive market products with higher levels of certain nutrients and varied flavors. In this sense, the objective of this study was to prepare mango and cajarana blends and determine the physical-chemical characte ristics and color parameters.

\section{Material and Methods}

The experiment was conducted at the Agricultural Products Processing Laboratory (LAPPA) at the Federal University of Campina Grande. The fruits were selected according to their integrity, those with injuries were discarded, washed in running water to remove dirt and sanitized in chlorinated solution $(200$ ppm of active chlorine) for $15 \mathrm{~min}$ and rinsed in running water, with subsequent drying at temperature environment and extraction of fruit pulps.

For the preparation of the blends formulations, three formulations were made: $\mathrm{Fl}$ - 50\% mango cv. espada pulp and 50\% cajarana pulp; F2 - 90\% mango cv. espada pulp and 10\% cajarana pulp and F3 - 10\% mango cv. espada pulp and $90 \%$ cajarana pulp. The pulps were homogenized (about 40 seconds), packed in plastic packaging, sealed and kept at $\sim 18^{\circ} \mathrm{C}$ until experimental analysis. The formulations prepared were evaluated in triplicate.

Color analysis was performed by direct reading using the MiniScan HunterLab XE Plus spectrophotometer, model $4500 \mathrm{~L}$, with a Cielab color system. The parameters determined were: $L^{*}$, which represents the luminosity, that is, the transition from black (0) to white (100); $a^{*}$ which represents the transition from the intensity of the green color $\left(-a^{*}\right)$ to the red color $\left(+a^{*}\right) ; b^{*}$ the transition from the intensity of the blue color $\left(-b^{*}\right)$ to the yellow color $\left(+b^{*}\right)$; from these values, the chroma values $\left(C^{*}\right)$ and the hue angle values (h) were calculated. The water activity was performed using the Aqualab model 3TE equipment (Decagon Devices, Inc.).

The physical-chemical parameters of $\mathrm{pH}$ were analyzed in a digital pHmeter, moisture content through direct drying in a vacuum oven $\left(70^{\circ} \mathrm{C}\right)$; ash by muffle incineration at $550^{\circ} \mathrm{C}$; total acidity titratable by titration with $0.1 \mathrm{~N} \mathrm{NaOH}$; total soluble solids ('Brix) by direct reading on a digital refractometer; protein content quantified according to the Kjeldahl method, where the total nitrogen content is determined and the total protein content is calculated by multiplying the nitrogen content by a factor of 6.25; total and reducing sugars were determined by the Fehling method by hot titration, and non-reducing sugars obtained by the difference between total and reducing sugars. All analyzes were performed according to the analytical procedures of the Adolfo Lutz Institute (IAL, 2008).

The lipid content was determined by the methodology of Bligh \& Dyer (1959) with chloroform, methanol and water. The ascorbic acid content was determined by titration with 2.6 dichlorophenolindophenol sodium (DCFI) until obtaining the light pink color, permanent using oxalic acid (Benassi \& Antunes, 1988) as an extracting solution, following the procedure AOAC (2009).

The experiment was installed in a completely randomized design, with three replications. The data were subjected to analysis of variance (ANOVA) and according to the significance of the F test, the Tukey test was applied at $5 \%$ probability, using the computer program ASSISTAT, version 7.7 Beta (Silva \& Azevedo, 2016).

\section{Results and Discussion}

Table 1 shows the average values of the physicochemical characterization of the blends formulations of mango and cajarana pulps. 
Table 1. Physico-chemical characterization of blends formulated with different concentrations of mango and cajarana pulps.

\begin{tabular}{|c|c|c|c|c|}
\hline Parameters analyzed & F1 & F2 & F3 & Teste F \\
\hline Total titratable acidity (\% citric acid) & $0.65 \pm 0.02^{b}$ & $0.27 \pm 0.02^{c}$ & $0.97 \pm 0.04^{a}$ & $557.1356 *$ \\
\hline $\mathrm{pH}$ & $3.03 \pm 0.01^{b}$ & $3.83 \pm 0.03^{a}$ & $2.77 \pm 0.01^{c}$ & $2322.6286^{* *}$ \\
\hline Total soluble solids ('Brix) & $14 \pm 0.00^{b}$ & $16 \pm 0.00^{a}$ & $12 \pm 0.00^{c}$ & $3600.0000^{* *}$ \\
\hline Moisture content (\%) & $85.06 \pm 0.18^{b}$ & $82.01 \pm 0.42^{c}$ & $86.77 \pm 0.08^{a}$ & $238.9566^{* *}$ \\
\hline Water activity $\left(a_{w}\right)$ & $0.98 \pm 0.00^{b}$ & $0.98 \pm 0.01^{a}$ & $0.99 \pm 0.01^{a}$ & $21.8824^{* *}$ \\
\hline Proteins (\%) & $0.65 \pm 0.05^{b}$ & $0.66 \pm 0.003^{b}$ & $0.91 \pm 0.13^{a}$ & $8.0528^{* *}$ \\
\hline Total sugars (\%) & $21.45 \pm 0.00^{\mathrm{b}}$ & $25.80 \pm 0.55^{a}$ & $18.48 \pm 0.00^{c}$ & $394.2360^{* *}$ \\
\hline Non-reducing sugars (\%) & $9.69 \pm 0.00^{a}$ & $11.60 \pm 2.34^{a}$ & $5.76 \pm 0.00^{b}$ & $14.6761^{* *}$ \\
\hline Reducing sugars (\%) & $11.29 \pm 0.00^{a}$ & $13.61 \pm 2.14^{a}$ & $12.39 \pm 0.00^{a}$ & $2.6391 \mathrm{~ns}$ \\
\hline Ascorbic acid (mg/100g) & $2.78 \pm 0.25^{a}$ & $2.62 \pm 0.33^{a}$ & $2.76 \pm 0.25^{a}$ & $0.3004 \mathrm{~ns}$ \\
\hline Lipids (\%) & $0.21 \pm 0.00^{a}$ & $0.25 \pm 0.03^{a}$ & $0.28 \pm 0.01^{a}$ & 0.7409 ns \\
\hline Ashes (\%) & $0.35 \pm 0.01^{a}$ & $0.38 \pm 0.14^{a}$ & $0.57 \pm 0.16^{a}$ & $1.9263 \mathrm{~ns}$ \\
\hline
\end{tabular}

For the values of total titratable acidity, it is observed that there was a statistical difference between the three formulations, however, there is a decrease in this parameter in F2, which may be associated with a higher proportion of mango pulp in the formulation, on the other hand, higher content of cajarana pulp (F3) provided an increase in total titratable acidity. According to current legislation (Brazil, 2018b) for mango and cajá pulp, the minimum requirements for this parameter correspond to 0.3 and $0.9 \%$ citric acid respectively, indicating that the cajarana pulp contributes with a greater proportion of acidity and that all formulations met the requirements when compared to the content required for the mango pulp, however when comparing with the values for the cajá pulp, only F3 met the requirements for having the highest proportion of cajarana pulp.

In the three formulations, the $\mathrm{pH}$ values were below 4.0, being classified as very acidic food. These low values are chosen by the industry as a good $\mathrm{pH}$ range in processing, due to the fact that under these conditions there is a minimization of enzymatic activities and microbial development (Gadelha et al., 2019). According to the legislation (Brazil, 2018b) the minimum $\mathrm{pH}$ required for the mango pulp is 3.5 and for the cajá 2.2, with the blends showing higher values than the cajá pulp. Higher pH values were determined by Silva et al. (2013) in papaya and acerola blends ranging from 4.47 to 4.77 .

The values of total soluble solids increased according to the greater amount of mango pulp in the formulation (F2), in contrast to the F3 with a higher concentration of cajarana pulp, presenting lower values. According to Brasil (2018b) the minimum content of total soluble solids in the mango and cajá pulp must be 11 and 9, respectively. Given these values, the blends showed higher values than the recommended for the mango pulp, indicating that factors such as variety, maturation stage, high average temperatures and high luminosity influence the photosynthetic activity of the plants, leading to an increase in the total soluble solids content in the fruits (Kluge et al., 2015).

The values found in this work for the contents of titratable acidity, $\mathrm{pH}$ and soluble solids, corroborate those verified by Faraoni et al. (2012) where they characterized pasteurized and frozen mango pulp, and obtained an acid content of $3.98 \%, \mathrm{pH} 3.98$, and soluble solids 20.08 ${ }^{\circ}$ Brix.

Silva et al. (2016) when analyzing a blend of pineapple with acerola, observed values of $0.73 \%$ of titratable acidity, $\mathrm{pH} 3.40$ and $10.26^{\circ}$ Brix. Santos et al. (2016) evaluated the content of soluble solids and $\mathrm{pH}$ of mango and cajá pulps, and detected levels (15.3 and $10.8{ }^{\circ}$ Brix; 4.07 and 3.24, respectively). Guimarães et al. (2020) evaluated the cajarana fruit with an average $\mathrm{pH}$ value of 2.90 , soluble solids $13.16^{\circ}$ Brix and $0.86 \%$ acidity. Chaves Neto \& Silva (2019), found an average pH of 2.28; soluble solids $14.61{ }^{\circ}$ Brix and $0.92 \%$ acidity in fruits from different microregions in the state of Paraíba, levels close to those reported in this research.

As for the moisture content, there are approximate values between $\mathrm{Fl}$ and F3, showing a trend in the reduction of water as the mango pulp increased (F2). However, there is a statistical difference between the formulations. According to Brasil (2018b) the maximum content of moisture content in the mango and cajá pulp must be 88.5 and 90.5, respectively, with the blends showing lower values. The moisture content in fruits is directly related to their perishability, thus making it necessary to use technological conservation processes in order to reduce losses in the industry (Khakimov et al., 2016).

Lemos et al. (2013) and Silva et al. (2016) evaluated the moisture content in a blend of "ortonique" orange and beet and pineapple pulp with acerola blend, however the values found (90.87 and $92.00 \%$ ) were 
higher than the values observed for the blends evaluated in this work. According to the Food Composition Table (TACO, 2011 ), mango contains $85.8 \%$ and cajarana $86.9 \%$ moisture content, which is lower than the other blends and similar to those found in this study.

The levels of water activity showed high results, with no significant difference between formulations F2 and F3, however, differing from formulation F1. The values in this parameter presented in this work are close to those reported by Silva et al. (2014) in umbu pulp, where it obtained 0.99, and by Oliveira et al. (2017) in mango cv. Rosa pulp of 0.982 .

For the protein content in the blends, it was found that there was an increase in the formulation with $90 \%$ (F3) of the cajarana pulp, differing statistically from other formulations $\mathrm{F} 1$ and F2. This higher content may be related to the amount of protein present in the fruit of the cajarana. According to TACO (2011) the cajarana fruit contains $1.3 \mathrm{~g} / 100 \mathrm{~g}$ and mango with 0.9 $\mathrm{g} / 100 \mathrm{~g}$ of protein. Low protein values were also found by Lago-Vanzela et al. (2011) and Damiani et al. (2011) in cajarana pulp, obtaining contents of 1.01 and $0.78 \%$, respectively, and by Czaikoski et al. (2016) that obtained $1.09 \%$ of mango pulp.

Regarding the total sugar content, it was found that the higher the concentration of the cajarana pulp, the lower the total sugar content, as observed in formulation F3. Lima et al. (2012) in their experiment with cajarana pulp, obtained average values for total sugars of $12.42 \%$, lower than those presented in the present study. Lemos et al. (2013) evaluating blend of orange and beet obtained for total sugar content, average $8.93 \%$, while Sousa et al. (2018) 12.43\% in buttermilk pulp.

The formulation with the highest amount of cajarana pulp (F3) showed a lower content of nonreducing sugars. Research carried out by Lemos et al. (2013) when evaluating orange and beet blend obtained an average of $2.10 \%$ for this parameter. Sousa et al. (2018) found $1.01 \%$ in fruits of the seriguela (Spondias purpurea) and Lima et al. (2012) in their study with backwoods pulp obtained lower values for non-reducing sugars of 6.12 and $5.99 \%$, when compared to $\mathrm{F} 1$ and $\mathrm{F} 2$.
It was observed that the formulations analyzed showed no statistical difference for the content of reducing sugars. In other studies, higher values reported by Sousa et al. (2018) are found in seriguela pulp $11.42 \%$ of reducing sugars, while Damiani et al. (2011) obtained $3.63 \%$ in this parameter in cajarana fruits.

Regarding the content of ascorbic acid present in the three formulations, they were considered low, ranging from 2.62 to $2.78 \mathrm{mg} / 100 \mathrm{~g}$, and did not differ statically from each other. According to TACO (2011), mango and cajarana have $7.9 \mathrm{mg} / 100 \mathrm{~g}$ and 26.7 $\mathrm{mg} / 100 \mathrm{~g}$, respectively, and according to Brasil (2018b) the minimum content of ascorbic acid in mango and cajá pulp must be 6.1 and $6.8 \mathrm{mg} / 100 \mathrm{~g}$. These low values found in blends are probably due to significant changes that occur in the presence of oxygen and as a function of the $\mathrm{pH}$ of the medium, among other conditions, leading to significant losses during processing or storage (Tarrago-Trani et al., 2012). The content of ascorbic acid in foods has an important function in processing, having a reducing action and is widely used as an antioxidant agent to stabilize color and flavor (Gadelha et al., 2019).

Regarding the lipid content, there was no significant difference between the samples. The low levels of lipids in the blends are consistent with the studies carried out by Lago-Vanzela et al. (2011) and Marques et al. (2010) who found values of $0.23 \%$ of lipids in cajarana pulp and $0,61 \%$ in mango pulp, respectively.

The ash content of the blends increased according to the increase in the proportion of cajarana pulp, with no statistical differences between the elaborated samples. The F3 sample had a higher ash content compared to the other samples, which can be justified by the greater amount of cajarana. According to TACO (2011) the ash content of cajarana is $0.4 \mathrm{~g} / 100 \mathrm{~g}$. Damiani et al. (2011), Sousa et al. (2018) and Guimarães et al. (2020) obtained higher values when they studied the characterization of cajá-manga $(0.45 \%)$, seriguela $(0.38 \%)$ and cajarana fruits $(0.89 \%)$.

Table 2 shows the average values of the physical color analysis.

Table 2. Average values of the color parameters $\left(L^{*},+a^{*},+b^{*}, C^{*}\right.$ and $\left.h^{*}\right)$ of mango blends with cajarana.

\begin{tabular}{ccccc}
\hline Parameters analyzed & F1 & F2 & F3 & Teste F \\
\hline Luminosity ( $\left.\mathrm{L}^{*}\right)$ & $48.94 \pm 0.14^{\mathrm{a}}$ & $46.12 \pm 0.12^{\mathrm{c}}$ & $47.50 \pm 0.15^{\mathrm{b}}$ & $292.1449^{* *}$ \\
Redness $\left(+\mathrm{a}^{*}\right)$ & $10.54 \pm 0.16^{\mathrm{a}}$ & $10.09 \pm 0.21^{\mathrm{b}}$ & $9.38 \pm 0.09^{\mathrm{c}}$ & $38.3201^{* *}$ \\
Yellowness (+b*) & $53.62 \pm 0.34^{\mathrm{b}}$ & $56.23 \pm 0.58^{\mathrm{a}}$ & $44.05 \pm 0.24^{\mathrm{c}}$ & $704.0121^{* *}$ \\
Chroma (C*) & $54.65 \pm 0.38^{\mathrm{b}}$ & $57.13 \pm 0.62^{\mathrm{a}}$ & $45.04 \pm 0.27^{\mathrm{c}}$ & $700.3509^{* *}$ \\
Hue angle ( $\left.\mathrm{h}^{*}-\mathrm{o}\right)$ & $78.88 \pm 0.52^{\mathrm{b}}$ & $79.82 \pm 0.86^{\mathrm{a}}$ & $78.02 \pm 0.37^{\mathrm{c}}$ & $86.7780^{* *}$ \\
\hline
\end{tabular}


There was a statistical difference between the blends for all the color parameters studied. In the luminosity parameter $\left(L^{*}\right)$, there was an increase according to the proportions of the cajarana pulp, that is, the fruit mixtures became clearer with the addition of this raw material. The yellowness value $\left(+b^{*}\right)$ increased gradually with the addition of the percentage of mango, as well as the parameter $+a^{*}$, which decreased following the reduction in the proportion of cajarana pulp. However, there is a predominance of yellowness, with higher levels, reflecting the color of the pulps used, when fruits are ripe.

Lemos et al. (2013) with orange and beet blend, obtained L* (8.99), $a^{*}$ (6.93) and b* (2.24). Silva et al. (2016) blend of pineapple and acerola $L^{*}$ (28.32), $a^{*}$ (35.30) and b* (28.38). Santos et al. (2016) mango pulp and cajá L* (18.47-22.00 and 18.29-24.30), h* (66.11-90.03 and 80.7388.80 $), C^{*}$ (14.14-26.03 and 14.12-19.24), respectively. The parameters related to color, no matter how much influence the health quality of the product, may be related to its acceptance by the consumer (Santos et al., 2016).

\section{Conclusions}

The blends of mango pulp and cajarana caused significant changes in most of the parameters evaluated, with an increase in the moisture content, ash, total titratable acidity, proteins and lipids as the concentration of the cajarana pulp was increased. The increase in the proportion of mango pulp favored the achievement of lighter blends, with a predominance of yellowness. The variability in the results in relation to the evaluated characteristics can be directly related to the influence that certain content present in each pulp had on another. However, the study showed a way to use these pulps in the preparation of blends, complementing their nutritional contents and the product is very promising.

\section{References}

AOAC. Association of Official Analytical Chemistry. 2009. Official methods of analysis of the Association of Official Analytical Chemistry. Association of Official Analytical Chemists, Washington, USA. $1115 \mathrm{p}$.

Asif, A., Farooq, U., Akram, K., Hayat, Z., Shafi, A., Sarfraz, F., Sidhu, M.A.I., Rehman, H., Aftab, S. 2016. Therapeutic potenctials of bioactive compounds from mango fruit residues. Trendency Food Science e Tecnology 53: 102112.

Benassi, M.T., Antunes, A.J.A. 1998. Comparison of metaphosphoric and oxalic acids as extratroctant solution for the determination of vitamin $C$ in selected vegetables. Arquivos de Biologia e Tecnologia 13: 507-573.

Bligh, E.G., Dyer, W.J. 1959. A rapid method of total lipid extraction and purification. Canadian Journal of Biochemistry and Physiology 37: 911-917.

BRASIL. Ministério da Agricultura e do Abastecimento. Instrução Normativa $n^{\circ} 49$, de 26 de setembro de 2018a. Complementação dos Padrões de Identidade e Qualidade de Suco e Polpa de Fruta. Diário Oficial [da] República Federativa do Brasil, Brasília, DF, 26 Sep. 2018.

BRASIL. Ministério da Agricultura e do Abastecimento. Instrução Normativa $n^{\circ}$ 37, de 01 de outubro de 2018b. Parâmetros analíticos de suco e de polpa de frutas e a listagem das frutas e demais quesitos complementares aos padrões de identidade e qualidade. Diário Oficial [da] República Federativa do Brasil, Brasília, DF, 01 Oct. 2018.

Buniowska, M., Carbonell-capella, J.M., Frigola, A., Esteve, M.J. 2017. Bioaccessibility of bioactive compounds after non-thermal processing of an exotic fruit juice blend sweetened with stevia rebaudiana. Food chemistry 221: 1834-1842.

Chaves Neto, J.R., Silva, S.M. 2019. Physical and physicalchemical characterization of fruits of Spondias dulcis Parkinson of different microregions of the State of Paraíba. Colloquium Agrariae 15: 18-28.

Cheuczuk, F., Rocha, L.A., Busanello, M.P., Castro-Cislaghi, F.P., Lunkes, A.M. 2018. Physicochemical, antioxidant and sensory properties of fermented milk beverage with added prebiotic and caja-manga pulp. Journal of Agrarian Sciences 46: 207-214.

Corbo, M.R., Bevilacqua, A., Petruzzi, L., Casanova, F.P., Sinigaglia, M. 2014. Functional Beverages: The Emerging Side of Functional Foods. Food Science and Food Safety 13: $1192-1206$.

Czaikoski, A., Czaikoski, K., Bezerra, J.R.M.V., Rigo, M. Teixeira, A.M. 2016. Preparation of ice cream with addition of mango (Tommy Atkins) pulp. Ambiência - Revista do Setor de Ciências Agrárias e Ambientais 12: 786-794.

Damiani, C., Silva, F.A., Amorim, C.C.M., Silva, S.T.P., Bastos, I.M., Asquieri, E.R.M., Vera, R. 2011. Mixed nectar of caja-manga with mint: chemical, microbiological and sensory characterization. Revista Brasileira de Produtos Agroindustriais 13: 299-307.

FAO. Food and Agriculture Organization of the United Nations. 2017. https://www.statista.com/statistics/577951/ world-mango-production/<Access on 02 Feb. 2020>

Faraoni, A.S., Ramos, A.M., Guedes, D.B., Oliveira, A.N., Lima, T.H.S.F., Sousa, P.H.M. 2012. Development of a mixed juice of mango, guava and acerola using mixture design. Ciência Rural 42: 911 -917.

Gadelha, M.R.A., Gomes, S.J., Silva, A.K., Alves, M.J.S., Santos, A.F. 2019. Blends with tropical fruits based on tamarindo. 2019. Green Journal of Agroecology and Sustainable Development 14: 412-419.

Guimarães, A.R.D., Leão, K.V., Mapeli, A.M., Schneider, L.C. 2020. Physical and chemical characterization of cajarana fruits (Spondias dulcis Parkinson). Brazilian 
Journal of Development 6: 6693-6701.

Henrique, P.C., Boas, A.C.V., Lima, R.A., Decarlos, A.N., Lima, L.C.O. 2016. Color, physicochemical parameters and antioxidant potential of whole grape juices subject to different UV-C radiation doses. Ciência e Agrotecnologia 40: 226-234.

Instituto Adolfo Lutz. 2008. Métodos físicoquímicos para análise de alimentos. Instituto Adolfo Lutz, São Paulo, Brazil. 1020 p.

Khakimov, B., Mongi, R.J., Sørensen, K.M., Ndabikunze, B.K., Chove, B.E., Engelsen, S.B. 2016. A comprehensive and comparative GC-MS metabolomics study of nonvolatiles in Tanzanian grown mango, pineapple, jackfruit, baobab and tamarind fruits. Food Chemistry 213: 691-699.

Kluge, R.A., Tezoto-uliana, J.V., Silva, P.P.M. 2015. Aspectos fisiológicos e ambientais da fotossíntese. Revista Virtual de Química 7: 56-73.

Lago-Vanzela, E.S., Ramin, P., Umsza-Guez, M.A., Santos, G.V., Gomes, E., Silva, R. 2011. Chemical and sensory characteristics of pulp and peel 'cajá-manga' (Spondias cytherea Sonn.) jelly. Food Science and Technology 31: 398-405.

Lauricella, M., Emanuele, S., Calvaruso, G., Giuliano, M., D'anneo, A. 2017. Multifaceted health benefits of Mangifera indica L. (mango): the inestimable value of orchards recently planted in Sicilian rural areas. Nutrients 9: 1-14.

Lemos, D.M., Figueirêdo, R.M.F., Queiroz, A.J.M., Silva, S.F., LIMA, J.C.B. 2013. Evaluation and physical chemistry of a blend of orange murcott 'Ortanique' and beet. Green Journal of Agroecology and Sustainable Development 7: 207-211.

Lima, E.Q., Oliveira, E., Lima, F.S., Neto, F.J.T. 2012. Caracterização Físico-Química e Bromatológica da Polpa de Spondias sp (Cajarana). Biofar: Revista de Biologia e Farmácia 7: 44-56.

Marques, A., Chicaybam, G., Araujo, M.T., Manhães, L.R.T., Sabaa-Srur, A.O. 2010. Mango rind and pulp (Mangifera indica L.) cv. Tommy Atkins centesimal composition and minerals contentes. Revista Brasileira de Fruticultura 32: 1206-1210.

Ravani, A., Joshi, D.C. 2013. Mango and is by product use - a review. Trends in Post-Harvest Tecnology 1: 55-67.

Santos, E.H.F., Neto, A.F., Donzeli, V.P. 2016. Physical, chemical and microbiological aspects of fruit pulps marketed in Petrolina (PE) and Juazeiro (BA). Brazilian Journal of Food Technology 19: 1-9.

Silva, C.E.F., Moura, E.M.O., Andrade, F.P., Gois, G.N.S.B., Silva, I.C.C., Silva, L.M.O., Souza, J.E.A., Abud, A.K.S. 2016. The importance of monitoring the identity and quality standards in fruit pulp industry. Journal of Bioenergy and Food Science 3: 17-27.

Silva, F.A.S., Azevedo, C.A.V. 2016. The Assistat Software Version 7.7 and its use in the analysis of experimental data. African Journal of Agricultural Research 11: 37333740 .

Silva, L.M.M., Santos, A.R.L., Silva, C.N., Souza, J.A.R., Arguello, V.M. 2014. Study the rheological behavior pulp and jelly umbu (Spondias tuberosa Arr.). Revista Brasileira de Produtos Agroindustriais 16: 411-422.

Silva, S.F., Figueirêdo, R.M.F., Queiroz, A.J.M., Lemos, D.M., Lima, J.C.B. 2013. Caracterização de blends de mamão formosa e figo-da-índia. Revista Verde de Agroecologia e Desenvolvimento Sustentável 7: 202-206.

Sousa, A.B.B., Nascimento, A.P.S., Araújo, A.K.P., Almeida, R.D., Cavalcanti, A.S.R. R.M., Duarte, M.E.M. 2018. Caracterização físico-química de polpa mista de ceriguela com spirulina platensis secas por liofilização. Revista Brasileira de Produtos Agroindustriais 20: 281-288.

TACO. Tabela Brasileira de Composição de Alimentos. 2011 . http://www.nepa.unicamp.br/taco/ <Access on 04 Mar. 2020>

Tarrago-Trani, M.T., Phillips, K.M., Cotty, M. 2012. MatrixSpecific Method Validation for Quantitative Analysis of Vitamin C in Diverse Foods. Journal of Food Composition and Analysis 26: 12-25.

Conflict of Interest Statement: The authors declare that the research was conducted in the absence of any commercial or financial relationships that could be construed as a potential conflict of interest.

All the contents of this journal, except where otherwise noted, is licensed under a Creative Commons Attribution License attribuition-type BY. 